\title{
Bond strength to dentin of total-etch and self-etch adhesive systems
}

\author{
Resistência de união à dentina de sistemas adesivos convencionais e autocondicionante
}

Ricardo Alves dos SANTOS 1

Eliane Alves de LIMA'

Mônica Maria de Albuquerque PONTES 1

Alexandre Batista Lopes do NASCIMENTO'

Marcos Antônio Japiassú Resende MONTES'

Rodivan BRAZ1

\section{ABSTRACT}

\section{Objective}

To assess the bond strength to dentin of the Single Bond (3M ESPE) and XP Bond (Dentsply) total-etch and Adper SE Plus (3M ESPE) self-etch adhesive systems.

\section{Methods}

Fifteen healthy human third molars were randomly allocated across three different groups of five teeth each according to the adhesive system. The occlusal portion of each tooth was removed under refrigeration using a flexible diamond disc (EXTEC, Enfield, CT, USA) down to an area of dentin that did not reveal enamel, as confirmed under a 40X stereo microscope (Ramsor, São Paulo, Brazil). A standardized smear layer was created with \#600 grit silicon-carbide paper. The adhesive systems were applied as per manufacturer recommendations, with the exception of the Adper SE Plus system, which was triple-polymerized. Composite resin blocks (5 mm) were placed on the dentin surface. The specimens were stored in distilled water for 24 hours at $37^{\circ} \mathrm{C}$. Using a flexible diamond disc (EXTEC, Enfield, CT, USA), toothpick-like specimens with an adhesive area of less than $1 \mathrm{~mm}^{2}$ were obtained. A microtensile bond test was then carried out using a universal testing machine (KRATOS) with a crosshead speed of $0.5 \mathrm{~mm} / \mathrm{min}$. Analysis of variance (ANOVA) and Tukey's test were used for comparisons.

\section{Results}

The bond strength values obtained with each adhesive system were as follows: XP Bond, 96.24 MPa; Adper Single Bond, 72.39 MPa; Adper SE Plus, $49.91 \mathrm{MPa}$.

\section{Conclusion}

In terms of bond strength to dentin, conventional adhesives outperform self-etching systems.

Indexing terms: Adhesive. Dentin. Tensile strength.

\section{RESUMO}

Objetivo

Avaliar o grau de resistência de união à dentina dos sistemas adesivos de condicionamento ácido total Adper Single Bond (3M ESPE) e XP Bond (Dentsply) e autocondicionante Adper SE Plus (3M ESPE).

\section{Métodos}

Quinze terceiros molares humanos hígidos foram utilizados, divididos aleatoriamente em três grupos de cinco dentes cada, conforme o adesivo que seria utilizado. A porção oclusal foi removida com o auxílio de um disco flexível diamantado sob refrigeração, até expor uma área de dentina que não apresentasse ilhas de esmalte, comprovado em lupa esterioscópica em aumento de 40X. A smear layer foi padronizada em lixa d'água $n^{\circ} 600$. Na sequência os sistemas adesivos foram aplicados conforme as recomendações do fabricante, exceto o Adper SE Plus que teve seu tempo de polimerização triplicado. Sobre os dentes preparados foram construídos blocos de resina composta com $5 \mathrm{~mm}$ de altura. As amostras foram armazenadas por 24 horas a $37^{\circ} \mathrm{C}$ em água destilada. Utilizando o disco flexível diamantado, foram obtidos corpos de prova com formato de palitos com área adesiva menor que $1 \mathrm{~mm}^{2}$. Em seguida o teste de microtração foi realizado numa Máquina de Ensaios Universal numa velocidade de 0,5 mm/min. Foram utilizados o teste ANOVA e comparações pareadas de Tukey.

\section{Resultados}

Os valores da resistência de união para cada sistema adesivo em Mpa foram: 96,24 (XP Bond); 72,39 (Adper Single Bond) e 49,91 (Adper SE Plus).

Conclusão

Dessa forma, em relação à resistência de união à dentina, os adesivos convencionais apresentaram desempenho superior ao autocondicionante.

Termos de indexação: Dentina. Adesivos. Resistência à tração.

\footnotetext{
${ }^{1}$ Universidade de Pernambuco, Faculdade de Odontologia. Av. Gal. Newton Cavalcanti, 1650, 54753-020, Camaragibe, PE, Brasil. Correspondência para / Correspondence to: RA SANTOS. E-mail: <ricardofop@gmail.com>.
} 


\section{INTRODUCTION}

Bonding to enamel is a technically straightforward and safe procedure ${ }^{1}$ due to the composition and structure of enamel, which is essentially inorganic and composed of prisms. On the other hand, the composition of dentin (which contains more water and organic substances) and its tubular structure (containing the cytoplasmic extensions of odontoblasts, varying in quantity and diameter, both of which increase with increasing proximity to the pulp) make bonding to dentin a challenge $\mathrm{e}^{2-3}$.

Acid etching of dentin may cause excessive exposure of the collagen fiber meshwork and thus limit the capacity for monomer infiltration to its fullest extent ${ }^{4-6}$. Collagen not embedded in monomers is susceptible to degradation, which can culminate in bond failure and reduce clinical longevity ${ }^{7-8}$. De Munck et al. ${ }^{9}$ state that, while acid conditioning of enamel is effective, stable, and durable, the same cannot be said for dentin.

Within this context, self-etch adhesive systems were developed. The key characteristic of these systems is that they skip the acid etching stage prior to application ${ }^{10}$, greatly decreasing the level of technical sensitivity required ${ }^{11}$, particularly because they obviate the need for optimal dentin moisture, which is required for total-etch systems $^{12-15}$. Unlike conventional adhesive systems, self-etch systems have added monomers added to their composition that ensure etching of the dental structure, so that, as soon as an area of the tooth is etched (or decalcified), it is immediately occupied by the resin monomer ${ }^{7,16}$.

Due to the limited conditioning ability of self-etch adhesive systems, the hybrid layer they form is thinner ${ }^{15,17-18}$ as compared to that of conventional adhesive systems. However, the quality of this layer has been noted as the most important factor ${ }^{19}$, despite the persistence of the smear layer in the hybrid layer ${ }^{20-21}$.

In view of the foregoing, this study sought to conduct an in vitro comparison, by means of the microtensile bond test, of the bond strength to dentin of two conventional, two-step adhesive systems (Adper Single Bond 2 and XP Bond) and of the self-etch Adper SE Plus system.

\section{METHODS}

The present study was approved by the University of Pernambuco Research Ethics Committee with registry number 143/09. Fifteen healthy third molars, extracted for surgical indications, were obtained from the Surgical Clinics of the University of Pernambuco School of Dentistry. After selection, the teeth were cleaned with a McCall 13-14 curette (Golgran-Millenium, São Paulo, Brazil) and a Robinson bristle brush (Microdont, São Paulo, Brazil) with pumice paste and water to remove any remaining soft tissue and detritus. The teeth were disinfected in $2 \%$ chlorhexidine (Maquira, Maringá, Brazil) for 30 minutes. The teeth thus prepared were stored in $0.9 \%$ saline solution at a temperature of approximately $5{ }^{\circ} \mathrm{C}$ until the start of the experimental portion of the study, for no more than 6 months. Saline was replaced with fresh solution once weekly.

For the subsequent laboratory stages, the roots of the teeth were embedded in 2.5-cm PVC tube segments containing self-polymerizing acrylic resin (VIPI FLEX, Pirassununga, Brazil).

To expose the dentin surface, the occlusion portion of each tooth was removed with a flexible diamond disc (EXTEC, Enfield, CT, USA) under refrigeration, perpendicular to the long axis, to a depth designed to mimic mediumsized cavities. After removal, the surfaces were assessed for the presence of remaining dentin islands under a 40X stereo microscope (Ramsor, São Paulo, Brazil). If any were visible, the occlusal surface was cut down further in 1-mm increments until exposure of a central zone composed exclusively of dentin, surrounded by a halo of enamel. The dentin surfaces were then abraded with \#600 grit silicon carbide paper for 1 minute to create a standardized smear layer.

The 15 teeth were randomly allocated across three groups according to the adhesive system to be tested. The composition of each system is described in Chart 1 . Teeth in group 1 (control) were treated with the Adper Single Bond 2 system (3M ESPE/St Paul, MN, USA), preceded by acid etching of dentin with $37 \%$ phosphoric acid (Condac 37, FGM, Joinville, Brazil) for 15 seconds, followed by rinsing with air/water spray from a triple syringe for 15 seconds and blotting with absorbent paper points, to obtain a moist, shiny dentin surface. The adhesive was then applied as per manufacturer instructions (Chart 2). Teeth in group 2 were treated with the self-etch Adper SE Plus system (3M ESPE, St Paul, MN, USA), which was applied directly to the teeth as per manufacturer instructions (Chart 2), with the exception of a longer polymerization time (30 seconds). This was based on a pilot study in which the manufacturer-recommended time of 10 seconds did not yield satisfactory specimens. Finally, teeth in group 3 were prepared as for group 1 and treated with the XP Bond system (Dentsply, Konstanz, Germany), in accordance with manufacturer instructions (Chart 2). 
Chart 1. Composition of materials used in the study.

\begin{tabular}{|c|c|c|}
\hline Material & Composition & Batch number \\
\hline $\begin{array}{l}\text { Adper Single Bond } 2 \\
\text { Control } \\
\text { (3M ESPE, St Paul, MN, USA) }\end{array}$ & $\begin{array}{c}\text { Ethyl alcohol, Bis-GMA, silane-treated silica, 2-hydroxyethyl methacrylate } \\
\text { (HEMA), glycerol 1,3-dimethacrylate, diurethane dimethacrylate, copolymer of } \\
\text { acrylic and itaconic acids }\end{array}$ & $9 \mathrm{WH}$ \\
\hline \multirow{2}{*}{$\begin{array}{l}\text { Adper SE Plus } \\
\text { (3M ESPE, St Paul, MN, USA) }\end{array}$} & \multirow{2}{*}{$\begin{array}{c}\text { Primer A; Water, 2-hydroxyethyl methacrylate, Rose bengal sodium. } \\
\text { Primer B: urethane dimethacrylate (UDMA), triethylene glycol dimethacrylate } \\
\text { (TEGDMA), trimethylolpropane trimethacrylate (TMPTMA), HEMA, methacrylated } \\
\text { phosphates (MHP), zirconia nanofiller, camphorquinone }\end{array}$} & Primer $\mathrm{A}: 8 \mathrm{BH}$ \\
\hline & & Primer B: 9BR \\
\hline $\begin{array}{l}\text { XP Bond } \\
\text { (Dentsply, Konstanz, Germany) }\end{array}$ & $\begin{array}{l}\text { Carboxylic acid modified dimethacrylate, phosphoric acid modified acrylate } \\
\text { resin, UDMA, TEGDMA, HEMA, stabilizer, ethyl 4-dimethylaminobenzoate, } \\
\text { camphorquinone, functionalized amorphous silica, } t \text {-butanol }\end{array}$ & 0906001157 \\
\hline $\begin{array}{l}\text { Filtek Z } 350 \\
\text { (3M ESPE, St Paul, MN, USA) }\end{array}$ & $\begin{array}{c}\text { Filler, Bis-EMA, diurethane dimethacrylate, bisphenol A diglycidyl ether } \\
\text { dimethacrylate, TEGDMA, pigment }\end{array}$ & $\begin{array}{l}\text { 9BL } \\
\text { 8UM } \\
\text { N108291 }\end{array}$ \\
\hline $\begin{array}{l}\text { Condac } 37 \\
\text { (FGM, Joinville, Brazil) }\end{array}$ & $37 \%$ phosphoric acid, thickening agent, coloring agent, deionized water & 161109 \\
\hline
\end{tabular}

Chart 2. Instructions for use as provided by the manufacturers.

\begin{tabular}{|ll|}
\hline System & Instructions for use \\
\hline Adper Single Bond 2 & $\begin{array}{l}\text { Apply two consecutive coats of adhesive to the tooth surface with gentle agitation for } 15 \text { seconds; gently } \\
\text { air thin; light cure for } 10 \text { seconds }\end{array}$ \\
Adper SE Plus & $\begin{array}{l}\text { Apply Liquid A to the entire bonding area so that a continuous red-colored layer is obtained on the surface; } \\
\text { apply Liquid B and scrub into the entire surface for } 20 \text { seconds; air dry thoroughly to evaporate water; apply } \\
\text { a second coat of Liquid B and lightly air thin; light cure for } 10 \text { seconds* }\end{array}$ \\
XP Bond & Apply to the entire surface; leave undisturbed for 20 seconds; dry thoroughly; light cure for 20 seconds
\end{tabular}

*As this duration did not yield satisfactory specimens during the pilot study, it was increased to 30 seconds.

After application of the adhesive systems, composite resin blocks were built up on the occlusal surface of each tooth, only on the region corresponding to dentin. Filtek Z 350 resin (3M ESPE, St Paul, MN, USA), shade $A 2$, was built up in increments of approximately $1 \mathrm{~mm}$. The height of each block was standardized at 5 $\mathrm{mm}$, as measured with digital calipers (Mitutoyo, São Paulo, Brazil). Each resin increment was polymerized for 40 seconds, using an LED light-curing unit with a wavelength of $440-480 \mathrm{~nm}$ and peak power of $1200 \mathrm{~mW} / \mathrm{cm}^{2}$ (Radiical, SDI, Australia). The teeth thus prepared were stored for 24 hours in distilled water in a warming cabinet (Fanem, São Paulo, Brazil) at $37^{\circ} \mathrm{C}$.

After 24 hours of storage at $37^{\circ} \mathrm{C}$, the PVC tube segments containing the teeth were again placed onto a cavity preparation machine (Elquip, São Paulo, Brazil), with which sequential, perpendicular cuts were performed, under constant cooling, along the mesiodistal and buccolingual axes, with a maximum thickness of $1 \mathrm{~mm}$. Finally, square rodshaped specimens were obtained by cutting the prepared teeth at the level of the dentin-enamel junction.

The resulting specimens were selected and mechanical testing performed, using a Bencor Multi-T device with a triangular cross-section jig to facilitate specimen placement. This device was attached to a universal testing machine (Kratos, São Paulo, Brazil). The machine was set up so that the load cell (2000 kgf) would be applied on the dentin/resin interface at a crosshead speed of $0.5 \mathrm{~mm} / \mathrm{min}$. Area of thickness and width values for each specimen were entered into the machine to yield strength measurements in megapascals (MPa).

Once a fracture had occurred, the specimen was examined under a 40X stereo microscope to ascertain the location of the fracture and whether it was adhesive or cohesive, in dentin or in resin. Specimens with cohesive fractures in dentin or in resin were excluded from analysis because they do not reflect the efficacy of bonding, but rather probable structural defects in dentin or resin ${ }^{18}$.

For statistical analysis purposes, each specimen was considered individually when calculating the mean bond strength of each adhesive system. Analysis of variance(ANOVA) and Tukey's pairwise comparisons test were performed, both with a significance level of $5 \%$. Levene's $F$ test was used to verify the assumption of equality of variances.

\section{RESULTS}

Table 1 shows bond strength results for each adhesive system. The highest mean bond strength was obtained with the XP Bond system, and the lowest, with the SE Plus system; these differences were significant $(p<$ 0.001) on Tukey's pairwise multiple comparisons test. 
Table 1. Bond strength statistics for each adhesive system.

\begin{tabular}{lcccc}
\hline & & System & & \\
\hline Statistic & Single Bond & SE Plus & & \\
\hline & & & & \\
Mean & $72.39^{(\mathrm{A})}$ & $49.91^{(\mathrm{B})}$ & $96.24^{(\mathrm{C})}$ & $p^{(1)}<0.001^{*}$ \\
Median & 71.54 & 47.71 & 89.34 & 31.88 \\
Standard deviation & 27.33 & 25.20 & 33.12 \\
Coefficient of variation & 37.75 & 50.49 & & \\
\hline
\end{tabular}

${ }^{*}$ ): Significant difference at the $5 \%$ level. (1): $F$ test (ANOVA).

Different superscript letters denote a significant difference across the corresponding adhesive systems on pairwise comparisons.

\section{DISCUSSION}

Due to the impossibility of obtaining adequate specimens during the pilot study, the cure time of the Adper SE Plus self-etch system (3M ESPE) was tripled. This change was supported by a previous study by Hashimoto ${ }^{21-22}$, which noted that increased polymerization time is associated with increased bond strength in self-etch systems.

It has been established that the quality of the hybrid layer, not its thickness, is associated with bond strength ${ }^{7,23}$. According to Oliveira et al. ${ }^{19}$, the high elastic modulus of the hybrid layer of self-etch systems is one of the factors associated with their excellent bond strength outcomes. Nevertheless, in view of the results of the present study - in which the selfetch system had the weakest bond strength to dentin - it is relevant to stress the work of Cal-Neto et al. ${ }^{18}$, who stated that the thickness of the hybrid layer and the length of the resin tags are not important in the bonding process, but the side branches and anastomoses that may form between resin tags in an adhesive system that relies on acid etching is a major contributing factor to mechanical strength.

Regarding the total acid-etch systems studied in this investigation, the XP Bond system achieved bond strengths to dentin significantly superior to those of the Adper Single Bond 2 system. This may be explained by the solvent used in the XP Bond system (tert-butanol, or t-butanol) and by the hypothesis that this adhesive system is capable of forming not only a micromechanical bond, but also a chemical bond to the tooth structure ${ }^{3,24}$.

The solvents present in adhesive system generally play two basic roles: to convey monomers into the collagen fiber meshwork of demineralized dentin and to assist in evaporation of the water that kept collagen fibers expanded 23,25 . The solvent used in total acid-etch systems is an important factor that affects handling and performance ${ }^{24}$. The Single Bond system uses a very interesting mix of two solvents (water and alcohol). According to Toledano et al. ${ }^{26}$, this gives it excellent wetting ability on etched dentin and helps keep collagen fibers expanded to ensure optimal infiltration by the adhesive system.

The XP Bond system employs a novel solvent, $t$-butanol. According to the manufacturer, this solvent improves performance because it prolongs the working time, significantly reduces sensitivity to operator technique, and provides high bond strengths to enamel and to dentin ${ }^{3}$. Structurally, tert-butanol consists of a C4 carbon and an alcohol functional group surrounded by three methyl groups, which makes it dissolve completely both in water, which is important for its infiltration into demineralized dentin, and in composite resins. The properties of $t$-butanol make it possible to increase the resin content of the adhesive system, which leads to increased thickness of the adhesive layer and high technical robustness as compared to other total acid-etch adhesives ${ }^{24}$. The latter characteristic is associated with the ability of this system to diffuse into demineralized dentin with a partially collapsed collagen meshwork, which makes it less sensitive to operator variability as compared to other acid-etch systems ${ }^{27}$.

Self-etch systems employ water as their main solvent. In addition to the basic roles of solvents in adhesive systems, in these products, water has the additional function of ionizing acid monomers, thus allowing them to condition the structure of the tooth ${ }^{10,28}$. Some self-etch systems combine water and another solvent to achieve better results. The Adper SE Plus system does not; its sole solvent is water. Due to its low vapor pressure, water may remain within the adhesive joint, weakening its physical and mechanical properties ${ }^{24}$. 
Software that simulates the composition and structure of dental substrates, dentin and collagen, can be used to assess whether adhesive systems are able to form a chemical bond with the structure of the tooth. This method has demonstrated that some adhesives - such as self-etch systems in general - can indeed form such a bond with the tooth. Once this bonding capability is scientifically confirmed, it will represent an advance in adhesive processes, due to its add-on effect to micromechanical bonding ${ }^{12,29}$. Raman microspectroscopy has demonstrated that the XP Bond system (Dentsply) contains phosphate esters capable of interacting chemically with the mineral components (apatite) of enamel and dentin. One hypothesis for the mechanism of this interaction is the formation of calcium phosphate complexes as a result of the chemical reaction between mineral components in dentin and phosphate esters in the adhesive ${ }^{29}$.

Despite the inferior results obtained with the selfetch system in the present study, before condemning all such adhesives as poorly performing, it is worth considering that different systems have distinct formulations, with different concentrations and types of acid monomers ${ }^{30}$. Therefore, the results obtained with the Adper SE Plus system cannot be fully extrapolated to other self-etch adhesives. Furthermore, it should be taken into account that there is no guideline for optimal bond strengths to dentin, only comparisons between different adhesives. When it comes to self-etch

\section{REFERENCES}

1. Perdigão J, Gomes G, Lopes MM. Influence of conditioning time on enamel adhesion. Quintessence Int. 2006;37(1):35-41.

2. Macari S, Gonçalves M, Nonaka T, Santos JM. Scanning electron microscopy evaluation of the interface of three adhesive systems. Braz Dent J. 2002;13(1):33-8.

3. Orellana N, Ramirez R, Roig M, Giner L, Mercade M, Duran F, et al. Comparative Study of the microtensile bond strength of three different total etch adhesives with different solvents to wet and dry dentin: in vitro test. Acta Odontol Latinoam. 2009;22(1):47-56.

4. Osorio R, Yamauti M, Ruiz-Requena ME, Toledano M. MMPs activity and bond strengthin deciduous dentine-resin bonded interfaces. J Dent. 2013;41(6):549-55. doi: 10.1016/j. jdent.2013.02.008

5. Perdigão J, Reis A, Loguercio AD. Dentin adhesion and MMPs: a comprehensive review. J Esthetic Rest Dent. 2013;25(4):219-41. doi: 10.1111/jerd.12016

6. Sabatini C. Effect of phosphoric acid etching on the shear bond strength of two self-etch adhesives. J Appl Oral Sci. 2013;21(1):56-62. doi: 10.1590/1678-7757201302370 systems, dental practitioners should consider the ability of these products to adapt to regional differences in dentin, their reduced potential for damage of this dental structure, and their lower dependence on patient and operatorrelated factors ${ }^{2,11,19}$. Therefore, self-etch systems appear to represent the future of bonding to dentin, as long as the industry continues to improve their formulations.

\section{CONCLUSION}

Under the conditions of this study, the XP Bond adhesive system exhibited the best bond strength to dentin, followed by the Adper Single Bond 2 system. Therefore, we conclude that total acid etch systems were superior to the Adper SE Plus self-etch adhesive.

\section{Collaborators}

RA SANTOS was involved in definition of the study topic, literature review, laboratory procedures, and manuscript writing. EA LIMA was in charge of literature review, laboratory procedures, and manuscript writing. MMA PONTES and ABL NASCIMENTO were involved in definition of the study topic, coordinated the laboratory stage, provided scientific guidance, and participated in manuscript writing. MAJR MONTES and R BRAZ provided scientific guidance and participated in manuscript writing.

7. Kenshima S, Reis A, Uceda-Gomez N, Tancredo LLF, Rodrigues Filho LE, Nogueira FN, et al. Effect of smear layer thickness and ph of self-etching adhesive systems on the bond strength and gap formation to dentin. J Adhes Dent. 2005;7(2):117-26.

8. Ribeiro AIAM, Dantas DCRE, Guênes GMT, Araújo RKP, Cyrilo CC, Braz R. Action of deproteinizing and antioxidant agents on the microtensile bond strength of conventional adhesives. RGO - Rev Gaúcha Odontol. 2011;59(2):221-7.

9. De Munck J, van Meerbeek B, Yoshida $Y$, Inoue $S$, Vargas $M$, Suzuki K, et al. Four-year water degradation of total-etch adhesives bonded to dentin. J Dent. 2003;82(2):136-40. doi: 10.1177/154405910308200212

10. Felizardo KM, Lemos LVFM, Carvalho RV, Gonini Junior A, Lopes MB, Moura SK. Bond stregth of HEMA-containing versus HEMA-free self-etch adhesive systems to dentin. Braz Dent J. 2011;22(6):468-72. doi: 10.1590/S0103-64402011000600005

11. Bortolatto JF, Takatsui F, Oliveira Junior OB, Andrade MF, Kuga MC, Campos EA. Effect of additional hydrofobic layer on the microtensile bond strenght of all-in one adhesive systems. Rev Odontol UNESP. 2011;40(3):113-7.

12. Vaidyanathan TK, Vaidyanathan J. Recent Advances in the Theory and Mechanism of Adhesive Resin Bonding to Dentin: A Critical 
Review. J Biomed Mater Res B Appl Biomater. 2008;88(2):55878. doi: 10.1002/jbm.b.31253

13. Gwinnett AJ, Kanca JA. Micromorphology of the dentin bonded interface and its relationship to bond strength. Am J Dent. 1992;52(2):75-7.

14. Aguilar-Mendonza JA, Rosales-Leal JI, Rodriguez-Valverde MA, González-Lopez S, Cabrerizo-Vílchez MA. Wettability and bonding of self-etching dental adhesives influence of the smear layer. Dent Mater. 2008;24(7):994-1000. doi: 10.1016/j. dental.2007.11.013

15. Arrais CAG, Giannini A. Morphology and thickness of the diffusion of resin through demineralized or unconditioned dentinal matrix. Pesqui Odontol Bras. 2002;16(2):115-20. doi: 10.1590/S1517-74912002000200004

16. Moura SK, Santos JFF, Ballester RY. Morphological Characterization of the Tooth/Adhesive Interface. Braz Dent J. 2006;17(3):179-85. doi: 10.1590/S0103-64402006000300001

17. Souza-Zaroni WC, Seixas LC, Ciccone-Nogueira JC, Chimello DT, Palma-Dibb RG. Tensile bond strength of different adhesive systems to enamel and dentin. Braz Dent J. 2007;18(2):124-8. doi: 10.1590/S0103-64402007000200007

18. Cal-Neto JOAP, Miranda MS, Dias KRHC. Comparative SEM evaluation of penetration of adhesive systems in human dentin with a non-rinse conditioner and a self-etching primer. Braz Dent J. 2004;15(1):19-25. doi: 10.1590/S0103-64402004000100004

19. Oliveira SSA, Pugach MK, Hilton JF, Watanabe LG, Marshall SJ, Marshall Jr GW. The influence of the dentin smear layer on adhesion: a self-etching primer vs.a total etch system. Dent Mater. 2003;19(8):758-67. doi:10.1016/S0109-5641(03)00023-X

20. Reis A, Grandi V, Carlotto L, Bortoli G, Patzlaff R, Accorinte $\mathrm{ML}$, et al. Effect of smear layer thickness ando $f$ self-etching solutions on early and long-term Bond strength to dentin. J Dent. 2005;33(7):549-59. doi:10.1016/j.jdent.2004.12.003

21. Shono $\mathrm{Y}$, Ogawa $\mathrm{T}$, Terashita $\mathrm{M}$, Carvalho RM, Pashley EL, Pashley DH. Regional measurements of resin-dentin bonding as an array. J Dent Res. 1999;78(2):699-705. doi: 10.1177/00220345990780021001
22. Hashimoto M. In vivo degradation of resin-dentin bonds in humans over 1 to 3 years. J Dent Res. 2000;79(6):1385-91. doi: $10.1177 / 00220345000790060601$

23. Meleo D, Manzon L, Pecci R, Zuppante F, Bedini R. A proposal of microtomography evaluation for restoration interface gaps. Ann Ist Super Sanitá. 2012;48(1):83-8. doi: 10.4415/ANN_12_01_14

24. Manhart J, Trumm MC. Microleakage of XP Bond in Class II Cavites After Artificial Aging. J Adhes Dent. 2007;9(2):261-4

25. Nihi FM, Fabre HSC, Georges Garcia G, Fernandes KBP, Ferreira FBA, Wang L. In vitro assessment of solvent evaporation from commercial adhesive systems compared to experimental systems. Braz Dent J. 2009;20(5):396-402. doi: 10.1590/ S0103-64402009000500007

26. Toledano M, Osório R, Albaladejo A, Aguilera FS, Osório E. Differential effect of in vitro degradation on resin-dentin bonds produced by self-etch versus total-etch adhesives. J Biomed Mater Rev A. 2005;77(1):128-35. doi: 10.1002/jbm.a.30656

27. Blunck $U$, Knitter $K$, Jahn $K R$. Six-month clinical evaluation of XP bond in noncarious cervical lesions. J Adhes Dent. 2007;9(6):265-8.

28. Tay FR, Pashley DH. Aggressiveness of contemporary selfetching systems.I: Depth of penetration beyond dentin smear layers. Dent Mater. 2001;17(4):296-308. doi:10.1016/S01095641(00)00087-7

29. Latta MA. Shear bond strength and physicochemical interactions of xp bond. J Adhes Dent. 2007;9(2):245-8.

30. Uekusa S, Tsubota K, Tonegawa M, Tsuchiya H, Iwasa M, Kawamoto R, et al. Microtensile bond strengths of single-step self-etch adhesive systems to bovine dentin. J Oral Sci. 2007; 49(3):183-9. doi: 10.2334/josnusd.49.183

Received on: 29/9/2013

Final version resubmitted on: 12/2/2014

Approved on: 25/3/2014 